\title{
SIKAP MAHASISWA TERHADAP DENOMINASI DAN REDENOMINASI RUPIAH
}

\author{
Zamroni \\ email: zamroni.psi@uin-malang.ac.id \\ Fakultas Psikologi \\ Universitas Islam Negeri Maulana Malik Ibrahim Malang
}

\begin{abstract}
The purpose of this study was to describe college student attitudes (positives or negatives) to denomination and redenomination issues of Rupiah. Study conducted by combining survey and thought experiment methods on 70 college students with 4 cases as treatment materials and 4 attitude scales as respon measurements which were valid and reliable. Result revealed that college students $89 \%$ would like to choose the smaller denomination, $57 \%$ respons negatively to negative effects of denomination, $20 \%$ respons negatively to the weakness of Rupiah competitiveness, and $24 \%$ respons positively to the redenomination of Rupiah. Weakness of Rupiah on the foreign currency impacts to the low collective self-esteem of Indonesian college students.
\end{abstract}

Keywords: Attitude, Student, Denomination, Redenomination, Rupiah

PSIKOISLAMIKA. Jurnal Psikologi Islam (JPI) copyright @ 2017 Pusat Penelitan dan Layanan Psikologi. Volume 14 Nomor 2 Tahun 2017

\section{PENDAHULUAN}

Redenominasi bagi beberapa kalangan, terutama pelaku pasar yang tidak berlatar belakang pendidikan ekonomi mungkin saja menganggap itu sebagai istilah baru. Akan tetapi, dalam praktik ekonomi seharihari pada dasarnya konsep tersebut sudah sering mereka lakukan, khususnya dalam perdagangan. Misalnya, penyebutan angka 1.000 (seribu) seringkali digunakan untuk menunjukkan nominal atau harga 1.000 .000 (satu juta). Selain itu, saat ini banyak dijumpai komoditas yang ditawarkan di pusat perbelanjaan dengan penyebutan harga atau denominasi yang sederhana, misalnya $10 \mathrm{~K}$ atau Rp. 10 yang berarti Rp. 10.000. Secara tidak langsung, fenomena ini menunjukkan bahwa masyarakat sebenarnya merasakan adanya kerumitan dalam menggunakan denominasi Rupiah saat ini untuk melakukan transaksi ekonomi.

Denominasi atau pecahan Rupiah yang saat ini beredar di masyarakat menurut banyak kalangan dinilai kurang efektif dan efisien. Banyaknya digit 0 (nol) menyebabkan inefisiensi dalam bekerja karena memiliki tingkat kerumitan penghitungan yang cukup tinggi dan keterbatasan infrastruktur alat penghitung uang (Dewi, 2013). Jumlah digit yang terlalu banyak dapat menimbulkan permasalahan transaksi karena infrastruktur sistem pembayaran dan sistem pencatatan tidak mampu mentolelir nilai transaksi dalam batas maksimum tertentu. Oleh karena itu, jumlah digit mata uang yang digunakan saat ini berpotensi menimbulkan inefisiensi dalam transaksi ekonomi. Selain itu, jumlah digit yang relatif banyak akan memunculkan persepsi terhadap nilai Rupiah yang lebih rendah dibandingkan mata uang asing (Alhusain, 2012; Kemenkeu \& BI, 2013).

Bank Indonesia (2013) telah mengumumkan beberapa dampak dari denominasi Rupiah yang besar saat ini. (1) inefisiensi perekonomian karena besarnya waktu dan biaya transaksi, kebutuhan pengembangan infrastruktur transaksi, dan meningkatnya biaya pengadaan uang. (2) Rupiah dipersepsikan bernilai sangat rendah karena nilai tukarnya atas mata uang asing termasuk paling rendah di antara negara ASEAN. (3) Kendala teknis akibat banyaknya digit angka, sehingga terjadi kesulitan dalam transaksi sehari-hari, dan bisa menimbulkan human error. Masyarakat akan beralih kepada mata uang asing, 
jika mereka kehilangan kepercayaan terhadap mata uang Nasional (Hasan, 2015).

Kondisi ini telah mendorong Bank Indonesia untuk mencari solusi agar perekonomian di Indonesia terus tumbuh dan berkembang melalui kebijakan moneter yang sehat. Salah satu kebijakan yang akan diberlakukan adalah redenominasi Rupiah untuk menciptakan sistem pembayaran yang sehat meliputi peredaran jumlah uang yang terkendali, pengaturan suku bunga, transaksi ekonomi yang efektif, efisien, cepat, aman, dan handal (Kesumajaya, 2015). Redenominasi adalah penyederhanaan jumlah digit pada denominasi atau pecahan Rupiah tanpa mengurangi daya beli, harga atau nilai tukar Rupiah terhadap harga barang atau jasa (Bank Indonesia, 2013). Redenominasi bisa dipahami sebagai suatu kebijakan pemerintah yang ditujukan untuk mengurangi inefisiensi dalam praktik ekonomi, serta membangun citra Rupiah yang mampu bersaing dengan mata uang asing, terutama tingkat ASEAN.

Suprijanto (2011) mengatakan bahwa redenominasi memiliki implikasi sosial dan ekonomi yang tidak sederhana, sehingga memerlukan kecermatan dalam sosialisasi serta komunikasi kepada masyarakat. Mahardika, dkk (2013) mengatakan bahwa faktor pemahaman konsumen atas rencana redenominasi, serta persepsi terhadap harga dan masa transisi sangat penting bagi keberhasilan penerapan kebijakan tersebut. Hasan (2015) mengatakan bahwa redenominasi mempengaruhi proses kognitif dan perilaku belanja masyarakat. Oleh karena itu, pemerintah harus mensosialisasikan secara gamblang dan menyeluruh kepada masyarakat agar tidak salah dalam menafsirkan redenominasi (Alhuasin, 2012).

Marques \& Dehaene (2004) menjelaskan dua proses kognitif yang terjadi pada diri individu (masyarakat) ketika pemerintah menerapkan suatu kebijakan nominal mata uang baru (redenominasi). (1) rescaling merupakan proses mentransformasi nilai mata uang lama ke dalam bentuk nilai mata uang baru, misalnya Rp. 10.000 ditransformasi menjadi Rp. 10. (2) re-learning merupakan proses menghafal dan mengingat harga baru komoditas yang berubah akibat pengurangan nominal mata uang. Kedua proses ini sangat penting dalam menentukan keberhasilan penerapan redenominasi untuk meningkatkan perekonomian. Beberapa kendala psikologis seringkali muncul, misalnya perasaan kehilangan uang yang disebabkan berkurangnya nominal mata uang, serta ketidakpercayaan masyarakat terhadap pemerintah karena dinilai merampas uang mereka (Hasan, 2015).

Gamble, et al. (2002) mengatakan bahwa Money Illusion Theory mampu menjelaskan mengapa individu mempersepsikan nilai mata uang baru lebih kecil dibandingkan dengan mata uang lama. Hal ini disebabkan nominal mata uang lama lebih besar dibandingkan uang baru. Meskipun pada proses rescaling, individu akan lebih mudah dalam mentransformasi nilai mata uang lama ke dalam bentuk nilai mata uang baru, namun dalam proses re-learning, individu akan mengalami kesulitan dalam menerapkan nilai mata uang baru pada harga komoditas dan jasa (Dzokoto \& Mensah, 2010), termasuk pertukaran uang. Kesulitan individu ini menjadi persoalan penting karena bisa menghambat penerapan kebijakan redenominasi Rupiah. Kondisi ini menjadi dilema bagi pemerintah, karena redenominasi di satu sisi bertujuan untuk meningkatkan citra Rupiah di mata uang asing, namun di satu sisi berpotensi memunculkan kecurigaan dan ketidakpercayaan masyarakat terhadap pemerintah yang dianggap merampas uang mereka.

Respon masyarakat Indonesia terhadap kebijakan redenominasi Rupiah adakalanya berbentuk positif maupun negatif. Respon ini disebut sebagai sikap individu terhadap suatu objek. Sikap sebagai bentuk kesiapan reaksi individu terhadap suatu objek, terutama dalam aspek afeksi maupun perasaan yang bermuatan evaluatif dibedakan atas dua bentuk, yaitu perasaan mendukung (favorable) dan tidak mendukung (unfavorable). Reaksi afektif ini menekankan bahwa objek sikap akan dinilai oleh individu mengenai benar atau salah, baik atau buruk, serta tepat atau tidak tepat (Azwar, 2008).

Untuk mengatasi respon yang muncul dari masyarakat (sikap positif maupun negatif), pemerintah telah membuat serangkaian kegiatan yang disusun dalam beberapa tahapan. Tahun 2017 merupakan tahap awal penerapan redenominasi Rupiah dengan melakukan penarikan uang lama dan digantikan dengan uang baru secara perlahan-lahan (Bank Indonesia, 2013). Tahap dan kegiatan redenominasi tersebut, jika ditinjau dari perspektif pengubahan perilaku (pikiran, perasaan, tingkah laku, dan fisiologi), memiliki kesamaan dengan prinsip pengubahan perilaku yang dikatakan oleh Wubbolding (dalam Corey, 2012) yang meliputi sederhana (simple), dapat dicapai (attainable), terukur (measurable), langsung (immediate), konsisten (consistent), terkontrol (controlled), dan komitmen (committed).

Berkenaan dengan respon berbeda-beda 
yang mungkin muncul, serta kesiapan pemerintah dalam menerapkan redenominasi Rupiah, maka perlu dilakukan survei mengenai kondisi kesiapan masyarakat Indonesia dalam menghadapi kebijakan tersebut. Penelitian ini bertujuan untuk menggali dampak positif maupun negatif yang akan muncul dari penerapan redenominasi. Informasi ini sangat penting dalam mandukung keberhasilan penerapan redenominasi, terutama berkaitan dengan kondisi psikologis dan perilaku ekonomi masyarakat. Kebijakan ini diharapkan bisa mengatasi masalah inefisiensi perekonomian, reputasi Rupiah yang buruk di mata uang asing, kendala teknis dan praktik penipuan dalam perdagangan, serta meningkatkan harkat dan martabat bangsa Indonesia agar masyarakat semakin percaya diri dengan mata uang yang dimilikinya.

\section{METODE}

Penelitian ini pada dasarnya merupakan penelitian survei yang bertujuan untuk mendeskripsikan gejala-gejala dan fenomena-fenomena (Suryabrata, 1983). Namun, dalam rangka memperoleh data yang akurat dan kontekstual, maka kondisi dilematis perlu dimunculkan pada diri responden ketika memberikan respon jawaban atas sikap mereka terhadap isu denominasi dan redenominasi. Oleh karenanya dibuatlah kasus-kasus sebagai bahan dalam menciptakan situasi yang terkendali, dan menggunakan desain thought experiment yang bertujuan untuk mempelajari proses kognitif, mengobservasi perilaku psikologis dengan memberikan stimulus dilematis (Sorensen, 1992).

Seperti halnya eksperimen lainnya, thought experiment memberikan berbagai variasi stimulus untuk kemudian direspon dalam bentuk perilaku atau respon pendapat seperti yang tertuang dalam angket atau skala. Stimulus yang digunakan dalam penelitian ini berupa kasus-kasus yang berhubungan dengan isu redenominasi Rupiah. Isu tersebut ditinjau dari (1) sikap individu terhadap denominasi Rupiah saat ini, (2) sikap individu terhadap dampak negatif yang dimunculkan dari denominasi Rupiah saat ini, (3) sikap individu terhadap daya saing Rupiah terhadap mata uang asing, dan (4) sikap individu terhadap rencana penerapan redenominasi Rupiah.

Desain penelitian yang digunakan adalah the only-shot case study (Suryabrata, 1983) yang terdiri atas empat seri eksperimen. Keempat seri tersebut dijelaskan pada Gambar 1 berikut:

\begin{tabular}{|l|l|l|}
\hline \multirow{2}{*}{ Eksperimen 1} & Treatment & Posttest \\
\cline { 2 - 3 } & X & T2 \\
\hline \multirow{2}{*}{ Eksperimen 2} & Treatment & Posttest \\
\cline { 2 - 3 } & X & T2 \\
\hline \multirow{2}{*}{ Eksperimen 3} & Treatment & Posttest \\
\cline { 2 - 3 } & X & T2 \\
\hline \multirow{2}{*}{ Eksperimen 4} & Treatment & Posttest \\
\cline { 2 - 3 } & X & T2 \\
\hline
\end{tabular}

Gambar 1:

Desain Eksperimen The Only-Shot Case Study

Sampel penelitian terdiri atas 70 mahasiswa Fakultas Psikologi Universitas Islam Negeri (UIN) Maulana Malik Ibrahim Malang. Sedangkan instrumen penelitian yang digunakan terdiri atas (1) skala sikap terhadap denominasi Rupiah yang memiliki reliabilitas Alpha sebesar 0,665 dan validitas aitem berkisar antara 0,380-0,597, (2) skala sikap terhadap dampak negatif denominasi Rupiah yang memiliki reliabilitas Alpha sebesar 0,906 dan validitas aitem berkisar antara 0,564-0,805, (3) skala sikap terhadap rendahnya daya saing Rupiah yang memiliki reliabilitas Alpha sebesar 0,832 dan validitas aitem berkisar 0,303-0,727, dan (4) skala sikap terhadap redenominasi Rupiah yang memiliki reliabilitas Alpha sebesar 0,899 dan validitas aitem berkisar antara 0,491-0,799.

\section{HASIL}

Berdasarkan hasil analisis diketahui bahwa pertama, sebagian besar mahasiswa akan membeli komoditas dengan label $100 \mathrm{~K}$ yang lebih sederhana dibandingkan dengan komoditas dengan label Rp. 100.000 yang lebih kompleks. $89 \%$ mahasiswa akan memilih denominasi yang sederhana, sedangkan sisanya $11 \%$ mahasiswa memilih denominasi yang kompleks. Denominasi yang sederhana dinilai secara positif oleh $29 \%$ mahasiswa, dinilai secara netral oleh $61 \%$ mahasiswa, dan dinilai secara negatif oleh $10 \%$ mahasiswa. Mahasiswa dalam merespon isu denominasi Rupiah saat ini yang cukup besar menunjukkan sikap yang kurang mendukung atau negatif. Sebagaimana diketahui $89 \%$ mahasiswa akan membeli komoditas dengan label $100 \mathrm{~K}$ dengan alasan (1) lebih murah (17\% mahasiswa), (2) lebih ringan (37\% mahasiswa), dan (3) tidak terbebani (48,5\% mahasiswa).

Kedua, sikap mahasiswa terhadap dampak negatif yang diakibatkan oleh keberadaan denominasi Rupiah saat ini yang beredar di masyarakat adalah $57 \%$ mahasiswa menilai secara negatif, $40 \%$ mahasiswa menilai secara netral, dan $3 \%$ mahasiswa menilai 
secara positif. Mahasiswa dalam merespon isu dampak negatif denominasi Rupiah saat ini menunjukkan sikap yang kurang mendukung atau negatif. Kebanyakan mahasiswa menilai kondisi denominasi Rupiah saat ini memiliki banyak kekurangan karena dirasa rumit dan mendorong pada praktik penipuan dalam perdagangan. Sebagaimana diketahui $57 \%$ mahasiswa memiliki penilaian secara negatif dengan alasan menimbulkan (1) tindakan kebohongan (64\% mahasiswa), (2) tindakan tercela (77\% mahasiswa), (3) tindakan salah (71\% mahasiswa), dan (4), merugikan (78,5\% mahasiswa), sehingga memunculkan perasaan (5) tersinggung (66\% mahasiswa), (6) marah (56\% mahasiswa), (7) kecurigaan (77\% mahasiswa), (8) konflik (76\% mahasiswa), (9) permusuhan $(70 \%$ mahasiswa), dan ingin (10) menghentikan (57\% mahasiswa).

Ketiga, sikap mahasiswa terhadap daya saing Rupiah atas mata uang asing juga menunjukkan $20 \%$ mahasiswa menilai secara negatif, 71\% mahasiswa menilai secara netral, dan $9 \%$ mahasiswa menilai secara positif. Mahasiswa dalam merespon isu daya saing Rupiah atas mata uang asing menunjukkan sikap yang kurang mendukung atau negatif. Sebagaimana ditunjukkan 20\% mahasiswa memiliki penilaian secara negatif terhadap kemampuan daya saing Rupiah atas mata uang asing. Rupiah sebagai identitas kolektif rakyat Indonesia berdampak pada persepsi rendahnya kemampuan dan harga diri rakyat Indonesia. Mahasiswa sebagai rakyat Indonesia merasa memiliki kemampuan yang lebih rendah dibandingkan negara lain dengan alasan merasa rugi ( $27 \%$ mahasiswa), merasa sial $(19 \%$ mahasiswa), merasa susah (31,5\% mahasiswa), dan merasa sedih (34\% mahasiswa) ketika menukarkan mata uang Rupiah dengan mata uang asing (Dolar). Selain itu, mereka juga merasa kurang memiliki harga diri dibandingkan negara lain dengan alasan merasa malu (43\% mahasiswa), merasa minder (44\% mahasiswa), dan merasa rendah diri $(31,5 \%$ mahasiswa).

Keempat, sikap mahasiswa terhadap rencana penerapan redenominasi Rupiah yang saat ini beredar di masyarakat adalah $24 \%$ mahasiswa menilai secara positif, $66 \%$ mahasiswa menilai secara netral, dan $10 \%$ mahasiswa menilai secara negatif. Mahasiswa dalam merespon isu rencana penerapan redenominasi Rupiah menunjukkan sikap yang mendukung atau positif. Kebanyakan mahasiswa menilai rencana penerapan redenominasi Rupiah sebagai langkah yang tepat dan tidak merugikan masyarakat. Sebagaimana ditunjukkan 24\% mahasiswa memiliki penilaian secara positif terhadap rencana penerapan redenominasi Rupiah dengan alasan redenominasi hanya menyederhanakan nominal, namun tidak mengurangi daya beli. Oleh karena itu mereka merasa (1) tenang $(41,5 \%$ mahasiswa), (2) tidak terbebani (46\% mahasiswa), dan (3) senang $(40 \%$ mahasiswa). Hal ini dikarenakan mereka tetap merasa (1) untung (30\% mahasiswa), (2) berharga (37\% mahasiswa), (3) mujur (33\% mahasiswa), dan (4) berguna (46\% mahasiswa).

Keempat sikap tersebut bisa dijelaskan secara ringkas dalam Gambar 2 berikut:

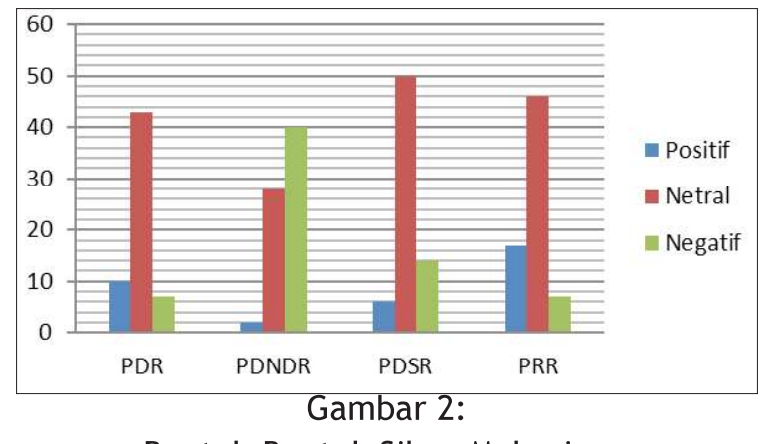

Bentuk-Bentuk Sikap Mahasiswa

Keterangan:

PDR=Penilaian terhadap denominasi Rupiah (sederhana)

PDNDR =Penilaian terhadap dampak negatif denominasi Rupiah

PDSR =Penilaian terhadap daya saing Rupiah

PRR = Penilaian terhadap rencana redenominasi

\section{DISKUSI}

Sejak tahun 2010 pemerintah sudah mencanangkan rencana penerapan kebijakan redenominasi Rupiah yang akan berlangsung sampai tahun 2020. Tahun 2017 merupakan tahap penerapan kebijakan redenominasi Rupiah sampai tahun 2018 yang di dalamnya semua uang kertas lama akan ditarik dan digantikan dengan uang kertas baru. Suprijanto (2011) mengatakan bahwa redenominasi memiliki implikasi sosial dan ekonomi yang tidak sederhana dan memerlukan kecermatan dalam sosialisasi serta komunikasi pada masyarakat.

Hasil survei menunjukkan bahwa $89 \%$ mahasiswa akan lebih memilih untuk membeli komoditas dengan label harga (denominasi) yang sederhana. Mereka mensikapi denominasi yang sederhana itu secara positif yang mencapai $29 \%$ mahasiswa. Sedangkan alasan mereka mengatakan dan bertindak demikian dikarenakan denominasi yang sederhana membuat 
mereka merasa ringan ( $37 \%$ mahasiswa) dan tidak merasa terbebani $(48,5 \%$ mahasiswa) dalam membelanjakan uang mereka demi memperoleh manfaat dari komoditas yang dibeli. Meskipun pada dasarnya mereka mengetahui dan menyadari bahwa komoditas yang akan dibeli itu harganya sama mahalnya $(23 \%)$, namun mereka merasa adanya keringanan dan tidak terbebani dalam membeli. Dengan kata lain, denominasi yang sederhana tidak berdampak pada penurunan harga diri individual dan kolektif mahasiswa berkenaan dengan keberadaan Rupiah.

Denominasi Rupiah yang sederhana dalam hal ini memiliki dampak positif bagi perkembangan perekonomian masyarakat Indonesia. Sebaliknya, denominasi Rupiah yang besar dan kompleks memiliki dampak yang negatif terhadap perkembangan perekonomian masyarakat Indonesia dikarenakan rumit dan kurang efisien, serta berpotensi terjadinya human error. Hal ini sebagaimana dikatakan oleh Dewi (2013) banyaknya digit nol saat ini menyebabkan inefisiensi bekerja karena memberikan tingkat kerumitan yang cukup tinggi dalam melakukan penghitungan, dan keterbatasan infrastruktur alat penghitung uang. Bank Indonesia (2013) mengumumkan bahwa jumlah digit mata uang yang digunakan saat ini berpotensi menimbulkan inefisiensi dalam transaksi ekonomi. Jumlah digit yang terlalu banyak dapat memunculkan permasalahan transaksi karena infrastruktur sistem pembayaran dan sistem pencatatan tidak mampu mengakomodir jumlah digit tersebut.

Hasil survei juga menunjukkan bahwa $57 \%$ mahasiswa mensikapi secara negatif terhadap dampak yang dimunculkan dari adanya denominasi Rupiah yang saat ini beredar di masyarakat. Beberapa dampak yang dimunculkan adalah praktik penipuan, ketidakadilan, dan perampasan hak konsumen dalam praktik jual-beli. Mereka mensikapi dan bertindak demikian dikarenakan tidak setuju dengan adanya pelanggaran tersebut. Mereka merasa tersinggung (66\% mahasiswa), marah (56\% mahasiswa), dan ingin menghentikan ( $57 \%$ mahasiswa) ketimpangan yang terjadi dalam praktik jual-beli di masyarakat. Sebagaimana diketahui bahwa salah satu pemicunya adalah denominasi Rupiah yang terlalu besar. Selain itu, mereka juga beralasan bahwa hal itu merupakan tindakan merugikan (78,5\% mahasiswa), tindakan tercela (77\% mahasiswa), tindakan salah (71\% mahasiswa), dan tindakan bohong $(64 \%$ mahasiswa) yang merugikan salah satu pihak, yaitu konsumen.
Dampak lain yang dimunculkan dari adanya ketimpangan tersebut berpotensi menimbulkan kecurigaan (77\% mahasiswa), konflik (76\% mahasiswa), dan permusuhan (70\% mahasiswa). Dampak tersebut merupakan buah dari adanya kekecewaan pada diri konsumen yang merasa dirugikan, dihilangkan, dan dirampas haknya, sehingga harga diri mereka merasa terganggu, terancam, dan mengarahkan pada munculnya tindakan-tindakan distruktif yang tidak diharapkan. Kondisi ini merupakan dampak dari ketidakberfungsian denominasi Rupiah yang saat ini beredar di masyarakat. Bank Indonesia (2013) mengumumkan bahwa denominasi yang besar berdampak pada kendala teknis akibat semakin banyaknya digit angka, sehingga terjadi kesulitan dalam transaksi sehari-hari, dan bisa menimbulkan risiko human error. Hal ini jika dibiarkan akan berdampak negatif pada disintegrasi bangsa.

Hasil survei juga menunjukkan bahwa $20 \%$ mahasiswa mensikapi secara negatif terhadap kemampuan atau daya saing Rupiah jika dibandingkan dengan mata uang asing. Rupiah sebagai salah satu identitas diri rakyat Indonesia juga dirasakan oleh mahasiswa. Rendahnya daya beli Rupiah terhadap mata uang asing menyebabkan mahasiswa merasa rugi ( $27 \%$ mahasiswa) dan sedih ( $34 \%$ mahasiswa), jika menukarkan uang Rupiah mereka dengan mata uang asing. Kondisi ini menyebabkan mahasiswa kurang memiliki kebanggaan dan harga diri kolektif terhadap mata uang Rupiah. Luhtanen \& Ctocker (1992) menyebut harga diri kolektif sebagai suatu perspektif baru dalam menjelaskan penilaian individu terhadap dirinya yang merupakan bagian dari kelompok sosialnya. Penilaian ini bersifat evaluasi terhadap identitas sosial atau identitas kolektif individu yang melampaui identitas personal dirinya. Harga diri personal dan kolektif ini pada dasarnya terus berkembang sepanjang kehidupan manusia (Hewitt, 2009), salah satu perjalanan kehidupan yang paling penting adalah isu denominasi dan redenominasi Rupiah yang bisa berdampak pada harga diri kolektif rakyat Indonesia.

Selain itu, harga diri mahasiswa sebagai warga negara Indonesia juga terusik dikarenakan daya saing Rupiah yang lemah. Mahasiswa merasa bahwa dirinya minder ( $44 \%$ mahasiswa), malu ( $43 \%$ mahasiswa), sedih (34\% mahasiswa), dan rendah diri (31,5\% mahasiswa) dalam menyandang identitas diri sebagai warga negara Indonesia. Bank Indonesia (2013) mengumumkan bahwa jumlah digit yang relatif banyak menciptakan persepsi rendahnya nilai Rupiah dibandingkan mata uang negara lain. Bank 
Indonesia juga mengumumkan bahwa denominasi yang besar memiliki dampak pada Rupiah yang dipersepsikan bernilai sangat rendah karena nilai tukar Rupiah atas mata uang asing termasuk terendah di antara negara ASEAN.

Hasil survei juga menunjukkan bahwa 24\% mahasiswa mensikapi secara positif terhadap rencana penerapan kebijakan redenominasi Rupiah. Sikap yang dimunculkan mereka cukup positif dan mengesankan adanya kesiapan dalam menerima dan menjalankan kebijakan pemerintah. Mereka mensikapi dengan tenang (41,5\% mahasiswa), merasa ringan (46\% mahasiswa), tidak terbebani ( $46 \%$ mahasiswa), dan senang (40\% mahasiswa) dalam mengemban amanat pemerintah tersebut. Mereka beralasan bahwa kebijakan redenominasi sangat menguntugkan (30\% mahasiswa), berharga (37\% mahasiswa), merasa mujur (33\% mahasiswa), dan berguna ( $46 \%$ mahasiswa) karena kebijakan tersebut hanya bersifat penyederhanaan nominal mata uang tanpa mengurangi daya belinya.

Sikap-sikap positif tersebut akan berpotensi membantu dan mendukung keberhasilan penerapan kebijakan redenominasi Rupiah. Mahardika, dkk (2013) mengatakan bahwa faktor pemahaman konsumen atas rencana redenominasi dan persepsi konsumen terhadap harga dan masa transisi sangat penting bagi keberhasilan penerapan kebijakan redenominasi. Dari hasil penelitian yang dilakukan Mardiana, dkk (2013) diketahui bahwa pemahaman konsumen atas redenominasi sudah cukup tinggi, meskipun mereka kurang yakin bahwa redenominasi akan bisa memperbaiki citra Rupiah yang saat ini di bawah mata uang asing.

Selain itu, penerapan kebijakan redenominasi Rupiah ini juga didukung strategi rencana dan pelaksanaan redenominasi yang memadai melalui tiga tahapan, yaitu tahap persiapan, tahap transisi, dan tahap pashing out. Tahapan ini memastikan bahwa penerapan kebijakan tersebut sifatnya tidak

\section{DAFTAR PUSTAKA}

Alhusain, A. S. (2012). Rencana redenominasi rupiah. Info Singkat Ekonomi dan Kebijakan Publik, IV(24), 13-16.

Azwar, S. (2008). Sikap manusia: teori dan pengukurannya (edisi ke-2). Yogyakarta: Pustaka Pelajar.

Bank Indonesia (2013). Konsultasi publik perubahan harga Rupiah 'redenominasi bukan sanering'. Kertas Kerja. terlalu memaksa dan berlebihan dalam mendorong masyarakat untuk mengikuti kebijakan dengan cara mengubah perilaku ekonomi mereka dari uang lama kepada uang baru. Tahapan ini dinilai sesuai dengan prinsip pengubahan perilaku yang dikatakan oleh Wubbolding (dalam Corey, 2012) yang meliputi sederhana (simple), dapat dicapai (attainable), terukur (measurable), langsung (immediate), konsisten (consistent), terkontrol (controlled), dan komitmen (committed). Ketuju prinsip inilah yang akan membantu individu dalam mengubah perilakunya secara bertanggung jawab dengan penuh kesadaran melalui perubahanperubahan kecil pada dirinya dalam penggunaan denominasi mata uang baru yang pada akhirnya akan mengarahkannya pada pemahaman tentang keberhasilan yang sudah dicapai untuk menghasilkan perubahan yang lebih besar.

\section{KESIMPULAN}

Berdasarkan hasil temuan penelitian yang sudah dipaparkan pada pembahasan sebelumnya, maka bisa disimpulkan bahwa sebagian besar mahasiswa akan lebih memilih komoditas dengan label harga yang lebih sederhana dengan alasan merasa lebih mudah dan tidak terlalu terbebani, bersikap negatif terhadap dampak negatif denominasi Rupiah yang saat ini beredar di masyarakat dengan alasan melanggar prinsip-prinsip perekonomian (peredagangan), menimbulkan konflik dan perseteruan, bersikap negatif terhadap daya saing Rupiah dengan alasan menurunkan harkat dan martabat Bangsa Indonesia dan harga diri kolektif rakyat Indonesia, serta bersikap positif terhadap rencana redenominasi Rupiah dengan alasan tidak terjadi perubahan apapun dari kepemilikan harta dan benda. Oleh karena itu, Bank Indonesia perlu memahami bahwa respon masyarakat cukup positif terhadap penerapan redenominasi Rupiah yang akan dilakukan oleh pemerintah, serta menjadikannya sebagai pijakan dalam mengambil keputusan.

Kementerian Keuangan dan Bank Indonesia (2013). Kebijakan redenominasi bukan sanering. Kertas Kerja, No. 11.

Corey, G. (2012). Theory and practice of group counseling ( $8^{\text {th }}$ ed.). Pacific Grove, CA: Brooks/Cole.

Dewi, K. (2013). Analisis dampak jika redenominasi dilakukan: Pengaruhnya terhadap daya beli masyarakat indonesia. Binus Business Review, 4(1), 489-490. 
Dzokoto, V. A. A. \& Mensah, E. C. (2010). Making sense of a new currency: an exploration of Ghanaian adaptation to the new Ghana Cedi. Journal of Applied Business and Economics,

Gamble, E., Gärling, T., Charlton, J. \& Ranyard, R. (2002). Euro illusion: Psychological insights into price evaluations with a unitary currency. European Psychologist, 7, 302-311.

Hasan, A. (2015). Ketidakadilan moneter pemicu kekacauan dan redenominasi (suatu kajian Islam). Ekonomika, 3(1), 94-105.

Hewitt, J. P. (2009). Self-esteem. In The encyclopedia of positive psychology (880-885). WilleyBlackwell.

Kesumajaya, I. W. W. (2015). Redenominasi mata uang rupiah merupakan bagian dari tugas bank indonesia untuk mengatur dan menjaga kelancaran sistim pembayaran di indonesia. GaneC Swara, 5(1), 129-134.
Luhtanen, R. dan Crocker, J. (1992). A collective self-esteem scale: Self-evaluation of one's social identity. The Society for Personality and Social Psychology, 18(3), 302-318.

Mahardika, H., Susianto, H., dan Narhetali, E. (2013). Dampak redenominasi rupiah terhadap konsumen. Policy Brief, 1.

Marques J. F. \& Dehaene, S. (2004). Developing intuition for prices in euros: rescaling or relearning prices? Journal of Experimental Psychology: Applied. 10(3), 148-155.

Sorensen, R. A. (1992). Thought experiment. Oxford University Press, Inc.

Suprijanto, A. (2011). UU tentang mata uang memberikan kepastian hukum bagi bangsa dan negara. Media Keuangan Kementerian Keuangan, VI(46), 6-8.

Suryabrata, S. (1983). Metodologi penelitian. Jakarta: Rajawali Pers. 